\title{
From Africa to Brazil: detection of African Oreochromis niloticus parasites in Brazilian fish farms
}

\author{
Da África para o Brasil: detecção de parasitos africanos de Oreochromis niloticus em \\ pisciculturas brasileiras
}

Diego Azevedo Zoccal Garcia ${ }^{1 *}$ (D), Mário Luís Orsi ${ }^{1}$ (D) and Ângela Teresa Silva-Souza ${ }^{2}$

${ }^{1}$ Programa de Pós-graduação em Ciências Biológicas, Laboratório de Ecologia de Peixes e Invasões Biológicas, Centro de Ciências Biológicas, Universidade Estadual de Londrina - UEL, Rodovia Celso Garcia Cid, CEP 86057-970, Londrina, PR, Brasil

${ }^{2}$ Programa de Pós-graduação em Ciências Biológicas, Centro de Ciências Biológicas, Universidade Estadual de Londrina - UEL, Rodovia Celso Garcia Cid, CEP 86057-970, Londrina, PR, Brasil *e-mail: diegoazgarcia@hotmail.com

\begin{abstract}
Aim: To evaluate the introduction of Oreochromis niloticus gill parasites in the Paranapanema River basin, northern Paraná, southern Brazil, as well as to inventory its occurrences in Brazilian fish farms and discuss the risks of transmission to native fauna. Methods: The gills of 632 fish specimens from four fish farms in the Paranapanema Basin were analyzed. The parasites were collected, processed and identified according to specific procedure. Literature review was carried out to compile records of occurrence of gill parasites species in other Brazilian river basins. Results: A total of seven (7) species of parasites were recorded, five (5) of the genus Cichlidogyrus, one (1) of Scutogyrus (Ancyrocephalidae, Monogenoidea) and one (1) of Lamproglena, Lamproglena monodi (Copepoda, Lernaeidae). All native from Africa. Some of these species have been reported in fish farms located in five other Brazilian watersheds. However, in this study a greater number of African gill parasite species was recorded in fish farms in northern Paraná (seven species), in the Paranapanema Basin, with Cichlidogyrus rognoni reported only for this basin. Conclusions: The results confirm the introduction of these African parasites along with their host, O. niloticus, and the establishment of these species in Brazilian waters, since many specimens belonging to the species identified herein presented breeding activity for at least one period of the year. Although, only L. monodi has been recorded parasitizing Brazilian native species, data reported for other countries demonstrates the imminent risk of transmission of these $O$. niloticus parasites to native cichlids.
\end{abstract}

Keywords: freshwater; non-native species; invasion; Neotropical; Nile tilapia.

Resumo: Objetivo: Avaliar a introdução de parasitos branquiais de Oreochromis niloticus na bacia do rio Paranapanema, norte do Paraná, sul do Brasil, assim como inventariar suas ocorrências em pisciculturas brasileiras e discutir os riscos de transmissão para a fauna nativa. Métodos: As brânquias de 632 espécimes de peixes de quatro estações de piscicultura na bacia do rio Paranapanema foram analisadas. Os parasitos foram coletados, processados e identificados de acordo com procedimento específico. A revisão da literatura foi realizada para compilar registros de ocorrência de espécies parasitas branquiais em outras bacias hidrográficas brasileiras. Resultados: Um total de sete (7) espécies de parasitos foi registrado, sendo cinco (5) do gênero Cichlidogyrus, uma (1) de Scutogyrus (Ancyrocephalidae, Monogenoidea) e uma (1) de Lamproglena, Lamproglena monodi (Copepoda, Lernaeidae), todas nativas da África. Algumas dessas espécies foram registradas em pisciculturas localizadas em outras cinco bacias hidrográficas brasileiras. No entanto, neste estudo, um número maior de espécies parasitas africanas foi registrado em pisciculturas no norte do Paraná (sete espécies), na bacia do rio Paranapanema, sendo Cichlidogyrus rognoni relatada apenas para essa bacia. 
Conclusóes: Os resultados confirmam a introdução destes parasitos africanos juntamente com o hospedeiro $O$. niloticus e o estabelecimento dessas espécies em águas brasileiras, uma vez que muitos espécimes pertencentes às espécies aqui identificadas apresentaram atividade reprodutiva por pelo menos um período do ano. Embora apenas L. monodi tenha sido registrada parasitando espécies nativas brasileiras, dados relatados para outros países demonstram o risco iminente de transmissão desses parasitos de $O$. niloticus para ciclídeos nativos.

Palavras-chave: água doce; espécies não nativas; invasão; Neotropical; tilápia do Nilo.

\section{Introduction}

Fish translocation has been carried out by human activities for a long time and for various purposes. Translocation is mainly intentional, with aquaculture, improvement of wild populations (fish stocking), fishing, biological control, and aquarium dumping as the main introduction vectors worldwide (Leprieur et al., 2008; Gozlan et al., 2010). Several negative effects caused by the introduction and subsequent invasion of fish species may occur, such as predation, habitat degradation, increased competition for resources, hybridization and disease transmission (Gozlan et al., 2010; Cucherousset \& Olden, 2011). Thus, invasive fish can affect a wide variety of native organisms, both directly and indirectly, at levels ranging from the genome to the ecosystem (Cucherousset \& Olden, 2011).

The native distribution of Nile tilapia, Oreochromis niloticus (Linnaeus, 1758) (Cichliformes, Cichlidae), is from North and East Africa, throughout the coastal rivers of Israel, the Nile River basin and several African lakes (Trewavas, 1983). It is widely distributed throughout several tropical and subtropical countries, due to aquaculture introduction (Eschmeyer et al., 2017; Froese \& Pauly, 2017).

In Brazil, the introduction of $O$. niloticus first ensued in the 1970s in the Brazilian Northeast, as the National Department of Drought Works (Departamento Nacional de Obras Contra a Seca - DNOCS) sought to populate dams during programs developed to fight hunger (Castagnolli, 1996). Since this event, the species has become intensely farmed in fish farms and 'fish and pay' establishments in several States and is currently farmed in practically the entire country (Borghetti \& Teixeira da Silva, 2008; Boscardin, 2008).

Although the introduction of $O$. niloticus was initiated with the aim of promoting the creation of developing economies, this species has caused serious environmental problems and threats to the native fish fauna in several countries, including the United States, Mexico, Australia, the Philippines, Madagascar, and Brazil, due to its high invasive potential (Froese \& Pauly, 2017; Cassemiro et al., 2018). The introduction of this species is of concern due to its ability to alter the invaded environment (Cassemiro et al., 2018), threatening native fish fauna by preying on fish in early development stages (i.e., eggs and larvae) and competing for space and food (Martin et al., 2010; Sanches et al., 2012). In the Americas, this species has promoted competitive displacement and alterations of reservoir water quality and phytoplankton communities (Figueredo \& Giani, 2005; Martin et al., 2010).

In Lakes Victoria and Kyoga, after its invasion, O. niloticus has predominated and drastically reduced the native Oreochromis esculentus (Graham, 1928) and Oreochromis variabilis (Boulenger, 1906) populations (Ogutu-Ohwayo, 1990; Maithya et al., 2012). The invasion of African tilapia (Oreochromis spp.) in Nicaragua lakes has also led to decreased native cichlid biomass and richness (McCrary et al., 2007).

As well as representing a direct biological risk for native fish fauna, O. niloticus invasion may also lead to the presence of other organisms, like parasitic species non-natives (Jiménez-García et al., 2001; Azevedo et al., 2012; Bittencourt et al. 2014a; Zago et al., 2014; Šimková et al., 2019). Co-introductions include parasitic species, and are a rarely documented risk, particularly in Brazil (Azevedo et al., 2012; Bittencourt et al., 2014a; Zago et al., 2014), as, most of the time, parasite introductions by hosts are neglected. Diseases caused by ectoparasites are variable, and may cause destruction of scales, abundant secretion of mucus, hyperplasia and necrosis of cells (Eiras, 1994). In some cases, fungi and bacteria invade the lesions, which can cause more serious consequences than those due to the parasitosis itself, in both farmed and wild fish (Eiras, 1994). Non-native parasite species alter natural parasite-host interactions, which may lead to anemia, low coefficient of condition (Yamamoto et al., 1984), and increase mortality among native host species (Prenter et al., 2004; Goedknegt et al., 2016).

In this context, we aimed to evaluate the introduction of $O$. niloticus gill parasites in earthen 
ponds and net cages in the Paranapanema River basin, southern Brazil, and compare this event with other Brazilian fish farms. In addition, we discuss the risks of transmission to native fish fauna.

\section{Material and Methods}

A total of 632 of juveniles and adults of O. niloticus specimens sexually reverted (males) donated by four fish farms in the northern Paraná State, Paranapanema Basin, were examined, from two net cages (22 $47^{\prime} 22.36^{\prime \prime} S, 51^{\circ} 17^{\prime} 46.53^{\prime \prime} \mathrm{W}$ and $\left.22^{\circ} 41^{\prime} 09.10^{\prime \prime} S, 51^{\circ} 17^{\prime} 49.88^{\prime \prime} \mathrm{W}\right)$ and two earthen ponds $\left(23^{\circ} 16^{\prime} 25.82^{\prime \prime} S, 51^{\circ} 26^{\prime} 23.70^{\prime \prime} \mathrm{W}\right.$ and $\left.23^{\circ} 16^{\prime} 57.59^{\prime \prime} \mathrm{S}, 51^{\circ} 25^{\prime} 30.81^{\prime \prime} \mathrm{W}\right)$. Of the 632 individuals, 156 specimens were obtained from earthen ponds and 476 from net cages. Samplings were carried out seasonally, from April 2010 to February 2011. Each specimen collected were dead and cooled. The gills of each specimen were removed and examined closely under stereomicroscope magnification. The parasites were collected and processed adequately according to Eiras et al. (2000). Each monogenoidean was identified according to the descriptions reported by Paperna (1964), Paperna \& Thurston (1969), Ergens \& Yukhimenko (1987), Douëllou (1993), Pariselle
\& Euzet (1995), Pariselle et al. (2003) and the determination key proposed by Pariselle \& Euzet (2009). Copepods were identified based on the redescriptions of Ibraheem \& Izawa (2000) and Azevedo et al. (2012).

A large literature review was carried out in order to compile records of occurrence of parasitic gill species in other Brazilian river basins, during January to May 2018. Only data published in scientific journals were considered. The research was conducted on the Web of Science, Scopus, Scielo and Google Scholar platforms, using the term 'Brazil' and combinations of the following terms: 'Monogenea', 'Monogenoidea', 'Ancyrocephalidae', 'Dactylogyridae', 'Cichlidogyrus', 'Scutogyrus', 'Lamproglena', 'Oreochromis', 'Nile tilapia'.

\section{Results and Discussion}

The literature review resulted in the compilation of nine studies on the occurrence of gill parasites in Brazilian river basins (Table 1). The following monogenoidean species were identified in fish farms in the Paranapanema River basin: Cichlidogyrus rognoni Pariselle, Bilong Bilong \& Euzet, 2003, C. sclerosus Paperna \& Thurston, 1969, C. thurstonae Ergens, 1981, C. halli (Price \& Kirk, 1967),

Table 1. Oreochromis niloticus gill parasites species of African origin detected in different Brazilian river basins.

\begin{tabular}{|c|c|c|}
\hline Species & Geographical distribution in Brazil & References \\
\hline \multicolumn{3}{|l|}{ Platyhelminthes } \\
\hline \multicolumn{3}{|l|}{ Monogenoidea } \\
\hline \multirow[t]{3}{*}{ Cichlidogyrus halli } & Grande River basin (MG/SP) & Zago et al. (2014) \\
\hline & Paranapanema River basin (SP/PR) & Britto \& Silva-Souza (2017), Present study \\
\hline & Itajaí River basin (SC) & Jerônimo et al. (2011) \\
\hline Cichlidogyrus rognoni & Paranapanema River basin (SP/PR) & Britto \& Silva-Souza (2017), Present study \\
\hline \multirow[t]{3}{*}{ Cichlidogyrus sclerosus } & Paranapanema River basin (SP/PR) & $\begin{array}{l}\text { Lizama et al. (2007), Britto \& Silva-Souza (2017), } \\
\text { Present study }\end{array}$ \\
\hline & Itajaí River basin (SC) & Ghiraldelli et al. (2006a), Jerônimo et al. (2011) \\
\hline & Uruguay River basin (SC) & Martins et al. (2014) \\
\hline \multirow[t]{4}{*}{ Cichlidogyrus thurstonae } & Grande River basin (MG/SP) & Zago et al. (2014) \\
\hline & Paranapanema River basin (SP/PR) & Britto \& Silva-Souza (2017), Present study \\
\hline & Itajaí River basin (SC) & Jerônimo et al. (2011) \\
\hline & Uruguay River basin (SC) & Martins et al. (2014) \\
\hline \multirow[t]{3}{*}{ Cichlidogyrus tilapiae } & Amazon River basin (AP) & Pantoja et al. (2012), Bittencourt et al. (2014a) \\
\hline & Paranapanema River basin (SP/PR) & Britto \& Silva-Souza (2017), Present study \\
\hline & Uruguay River basin (SC) & Martins et al. (2014) \\
\hline \multirow[t]{4}{*}{ Scutogyrus longicornis } & Grande River basin (MG/SP) & Zago et al. (2014) \\
\hline & Paranapanema River basin (SP/PR); & Britto \& Silva-Souza (2017), Present study \\
\hline & Itajaí River basin (SC) & Jerônimo et al. (2011) \\
\hline & Uruguay River basin (SC) & Martins et al. (2014) \\
\hline \multicolumn{3}{|l|}{ Crustacea } \\
\hline \multicolumn{3}{|l|}{ Copepoda } \\
\hline \multirow[t]{2}{*}{ Lamproglena monodi } & Paraíba do Sul River basin (RJ) & Azevedo et al. (2012) \\
\hline & Paranapanema River basin (SP/PR) & Present study \\
\hline
\end{tabular}

MG: state of Minas Gerais; SP: state of Sáo Paulo; PR: state of Paraná; SC: state of Santa Catarina; AP: state of Amapá. 
C. tilapiae Paperna, 1960, and Scutogyrus longicornis (Paperna \& Thurston, 1969), all originating from Africa (Table 1). These six monogenoidean species recorded herein in $O$. niloticus gills were found in an earthen pond from another fish farm in northern Paraná (Britto \& Silva-Souza, 2017). Five Cichlidogyrus species, comprising C. sclerosus and four unidentified species, were recorded infesting $O$. niloticus gills in specimens raised in ponds in the state of São Paulo, also in the Paranapanema River basin (Lizama et al., 2007). Four Cichlidogyrus species were recorded in net cages, two of which unidentified, in addition to $S$. longicornis, in the Água Vermelha Reservoir, Grande River basin, located in the state of São Paulo (Zago et al., 2014). Nile tilapia reared in net cages in the Guarapiranga Reservoir, also in the state of Sáo Paulo, were infested by Cichlidogyrus sp.

In southern Brazil, five species have also been reported in ponds in different fish farms in the state of Santa Catarina, in the Itajaí River basin (Ghiraldelli et al., 2006a, Jerônimo et al., 2011) and in the Uruguay River basin (Martins et al., 2014). On the other hand, only $C$. tilapiae was recorded in the state of Amapá, northern Brazil, in four fish farms (Pantoja et al., 2012). Thus, the high number of African parasitic gill species recorded in northern Paraná fish farms, in the Paranapanema Basin, is noteworthy, with $C$. rognoni being found only in this basin to date.

In Africa, Ancyrocephalidae (Monogenoidea) is the family with most representatives of gill parasites infesting Oreochromis Günther, 1889, Coptodon Gervais, 1853 (=Tilapia Smith, 1840), and Sarotherodon Rüppell, 1852. Oreochromis niloticus gill parasites are distributed in two genera: Cichlidogyrus Paperna, 1960 and Scutogyrus Pariselle \& Euzet, 1995 (Pariselle, 1995; Pariselle \& Euzet, 2009). Cichlidogyrus sclerosus, present in three Brazilian hydrographic basins (Table 1), was introduced in Colombia (Kritsky \& Thatcher, 1974) and in Mexico (Kritsky et al., 1994). On the other hand, C. tilapiae, also reported in three Brazilian basins, including the Amazon Basin, was registered in Cuba by Prieto et al. (1985). These records demonstrate that this group of African parasites presents a wide distribution in the Neotropical region, where they presented tolerance and adjustment to the new environment.

The six species of Monogenoidea recorded displayed breeding activity for at least one period of the year in fish farming activities also carried out in northern Paraná (Britto \& Silva-Souza,
2017). In the present study, although they were not quantified, individuals from the same species of egg-containing gill parasites were found in all evaluated fish farms. These results allow us to consider that these African species are established and adjusted to the environments where their hosts are being reared and, therefore, propagule pressure of the recorded parasites has been potentiated.

Lamproglena monodi Capart, 1944 (Copepoda Lernaeidae), also from Africa, was registered in one of the fish farms containing earthen ponds (Table 1). Lamproglena von Nordmann, 1832 comprises 41 freshwater fish parasite species (Piasecki, 2008) distributed throughout Africa (Douëllou \& Erlwanger, 1994; Ibraheem \& Izawa, 2000; Hassan et al., 2013; Marzouk et al., 2013; Sinaré et al., 2016), Asia (Kumari et al., 1989; Yambot \& Lopez, 1997) and Europe (Galli et al., 2001). In Brazil, Lamproglena sp. has been reported since the year 2000 in the states of Sáo Paulo, Rio de Janeiro and Santa Catarina (Alves et al., 2000; Azevedo et al., 2006; Ghiraldelli et al., 2006a; Ghiraldelli et al., 2006b; Lizama et al., 2007; Martins et al., 2010). According to Douëllou \& Erlwanger (1994), Lamproglena monodi, a gill parasite of several species of cichlids, has Coptodon rendalli (Boulenger, 1897) as one of its preferred hosts. However, in Brazil, L. monodi has been recorded in freshwater environments as both a parasite of $O$. niloticus and $C$. rendalli (Azevedo et al., 2010; Azevedo et al., 2012; Tavares-Dias et al., 2015). Such records confirm that $O$. niloticus has brought along partly or all of its native parasites when introduced in Brazil (Britto \& Silva-Souza, 2017).

The lack of data on fish farmed during the last 15 years does not allow for conclusions regarding L. monodi introduction in Brazil (Martins et al., 2010). However, this crustacean was found as a parasite in Amazonian cichlid populations introduced in the Guandu River, in the state of Rio de Janeiro, namely Astronotus ocellatus (Agassiz, 1831) and Cichla ocellaris Bloch \& Schneider, 1801 (Azevedo et al., 2010) (Table 1). According to Tavares-Dias et al. (2015), L. monodi is distributed throughout the Paraná, Uruguay and Atlantic Ocean River systems.

A lower number of gill parasites species was recorded infesting $O$. niloticus in fish farms located in the states of Minas Gerais, Rio de Janeiro, São Paulo, Santa Catarina and Amapá (Table 1). Oreochromis niloticus was introduced in 1994 in some fish farms in the municipality of Macapá, 
in the state of Amapá, eastern Amazon region, in northern Brazil (Tavares-Dias, 2011). Between 2000 and 2001, several reports were made of $O$. niloticus escapes due to pond overflowing by heavy rains (Tavares-Dias, 2011). Oreochromis niloticus, an invasive species in the Igarapé Fortaleza basin, was infested with Ichthyophthirius multifliis Fouquet, 1876, Trichodina centrostrigeata Basson, Van As \& Paperna, 1983, Paratrichodina africana Kazubski \& El-Tantawy, 1986, Trichodina nobilis Chen, 1963, and Cichlidogyrus tilapiae, with no common parasite species to the native Amazonian ecosystem fish fauna. On the other hand, T. nobilis, a trichodinid parasite of $O$. niloticus, was transmitted to the native basin cichlid, Aequidens tetramerus (Heckel, 1840) (Bittencourt et al., 2014a, b). However, nothing is known about Brazilian watershed native fish infestations by African monogenoidean parasites of O. niloticus gill. Nevertheless, in Mexico, after the introduction of $O$. niloticus, infestation of the native species Vieja fenestrata (Günther, 1860) (= Cichlasoma fenestratum) (Cichlidae) by Scutogyrus longicornis (= Cichlidogyrus longicornis) was observed (Jiménez-García et al., 2001). This monogenoidean species was detected in four Brazilian watersheds.

In Brazil, O. niloticus is the most farmed species and corresponds to $45.4 \%$ of the total fish production in the country, with the state of Paraná (southern region) as the largest producer, totaling $28.8 \%$ (Brasil, 2017). The species is farmed both in earthen ponds and in net cages located in reservoirs. Even if the species is only reared in earthen ponds, these constructions are usually built close to riverine areas subject to flooding, and fish escapes may occur during rainy periods (Casimiro et al., 2018).

In the summer of $2015 / 16$, about 1.14 million fish belonging to 21 species and three hybrids escaped from fish farms to the Paranapanema River basin. Of this total, $96 \%$ comprised $O$. niloticus and $C$. rendalli specimens (Casimiro et al., 2018). It is important to note that $O$. niloticus specimens had already been recorded in the Capivara Reservoir (Paranapanema River) (Orsi $\&$ Britton, 2014). The presence of $O$. niloticus in the Grande and Uruguay river reservoirs and in the Amazonas River were reported, respectively, by Azevedo-Santos et al. (2011), Schork et al. (2013) and Bittencourt et al. (2014a). On the other hand, no records of $O$. niloticus in natural Itajaí River basin environments are available.

In this context, and according to the findings for fish farms in northern Paraná, in the Paranapanema River basin, as well as other Brazilian watersheds, an imminent risk of transmission of $O$. niloticus parasites to cichlids, such as Australoheros Rican \& Kullander, 2006, Aequidens Eigenmann \& Bray, 1894, Cichlasoma Swainson, 1839, Crenicichla Heckel, 1840, Geophagus Heckel, 1840, and Gymnogeophagus Miranda Ribeiro, 1918, is noted (Langeani et al., 2007). The consequences of the association of these Africa parasites to native fish are still unclear, but there may be a risk of increased mortality as recorded for cichlids in Florida (Noga \& Flowers, 1995). Ectoparasites may cause injuries of scales, secretion of mucus and necrosis of cells, which allow the entry of fungi and bacteria (Eiras, 1994). The pathogens caused by these parasites alter parasite-host interactions and reduce the native host population (Prenter et al., 2004; Goedknegt et al., 2016). Therefore, fish translocation by human intervention provides a window of opportunity for new interactions that threaten biodiversity.

It is important to note that the results presented and reported herein may not represent the actual distribution of parasitic species in Brazil, as these findings represent only the places where published studies took place. Due to the large size of the Brazilian territory, we detected the lack of information on the distribution of these parasites in several regions of the country, such as the northeast region where the first case of introduction of $O$. niloticus occurred. However, such records confirm that $O$. niloticus has introduced non-native parasites.

Thus, we suggest that, safety ponds should be installed in fish farms, to allow the water treatment prior to release in nearby springs. Fish farm inspection should be increased, and if escape events are proven, the National Environmental Policy that establishes the 'polluter pays' principle should be applied to the fish farmer. Non-native species are considered a form of environmental pollution and may be a serious impact on aquatic ecosystems (França et al., 2017; Casimiro et al., 2018). Therefore, the correct identification and survey of the distribution of non-native parasites are essential to maintain the integrity of Brazilian aquatic ecosystems. In addition, lay people, fish farmers and fishermen should be made aware of how to combat non-native species.

\section{Acknowledgements}

The authors are grateful to students and volunteers who participated in data collection and to the fish farm that donated the fish specimens; and editor and anonymous reviewers for suggesting 
manuscript improvements. This work was supported by the Conselho Nacional de Desenvolvimento Científico e Tecnológico - CNPq (grant number 472648/2009-8).

\section{References}

ALVES, D.R., LUQUE, J.L. and PARAGUASSÚ, A.R. Ectoparasitos de tilápia nilótica Oreochromis niloticus (Osteichthyes: Cichlidae) da Estação de Piscicultura da UFRRJ. Revista de Ciências da Vida, 2000, 22(1), 81-85.

AZEVEDO, R.K., ABDALLAH, V.D. and LUQUE, J.L. Acanthocephala, Annelida, Arthropoda, Myxozoa, Nematoda and Platyhelminthes parasites of fishes from the Guandu river, Rio de Janeiro, Brazil. Check List, 2010, 6(4), 659-667. http://dx.doi. org/10.15560/6.4.659.

AZEVEDO, R.K., ABDALLAH, V.D., SILVA, R.J., AZEVEDO, T.M., MARTINS, M.L. and LUQUE, J.L. Expanded description of Lamproglena monodi (Copepoda: Lernaeidae), parasitizing native and introduced fishes in Brazil. Revista Brasileira de Parasitologia Veterinária, 2012, 21(3), 263-269. http:// dx.doi.org/10.1590/S1984-29612012000300015. PMid:23070437.

AZEVEDO, T.M.P., MARTINS, M.L., BOZZO, F.R. and MORAES, F.R. Haematological and gill responses in parasitized tilapia from valley of Tijucas River, SC, Brazil. Scientia Agrícola, 2006, 63(2), 115-120. http://dx.doi.org/10.1590/S010390162006000200002.

AZEVEDO-SANTOS, V.M., RIGOLIN-SÁ, O. and PELICICE, F.M. Growing, losing or introducing? Cage aquaculture as a vector for the introduction of nonnative fish in Furnas Reservoir, Minas Gerais, Brazil. Neotropical Ichthyology, 2011, 9(4), 915-919. http://dx.doi.org/10.1590/S167962252011000400024 .

BITTENCOURT, L.S., PINHEIRO, D.A., CÁRDENAS, M.Q., FERNANDES, B.M. and TAVARES-DIAS, M. Parasites of native Cichlidae populations and invasive Oreochromis niloticus (Linnaeus, 1758) in tributary of Amazonas River (Brazil). Revista Brasileira de Parasitologia Veterinária, 2014a, 23(1), 44-54. http://dx.doi.org/10.1590/ S1984-29612014006. PMid:24728360.

BITTENCOURT, L.S., SILVA, U.R.L., SILVA, L.M.A. and DIAS, M.T. Impact of the invasion from Nile tilapia on natives Cichlidae species in tributary of Amazonas River, Brazil. Biota Amazônia, 2014b, 4(3), 88-94. http://dx.doi.org/10.18561/2179-5746/ biotaamazonia.v4n3p88-94.

BORGHETTI, J.R. and TEIXEIRA DA SILVA, U.A. Principais sistemas produtivos empregados comercialmente. In: OSTRENSKY, A., BORGHETTI, J.R. and SOTO, D., eds. Aquicultura no Brasil: o desafio é crescer. Brasília: FAO, 2008, pp. 73-94.

BOSCARDIN, N.D. A produção aquícola brasileira. In: OSTRENSKY, A., BORGHETTI, J.R. and SOTO, D., eds. Aquicultura no Brasil: o desafio é crescer. Brasília: FAO, 2008, pp. 27-72.

BRASIL. Produção de tilápia cresce mais de $200 \% \mathrm{em}$ dez anos no Brasil. Ministério da Agricultura, 2017 [viewed 04 Dec. 2017]. Available from: http:// www.brasil.gov.br/economia-e-emprego/2017/04/ producao-de-tilapia-cresce-200-em-dez-anos-nobrasil/

BRITTO, Y.C.T. and SILVA-SOUZA, Â.T. Temporal variation of monogenoideans component community in the gills of Oreochromis niloticus (Cichlidae) in fish farming in northern Parana state, Brazil. PanAmerican Journal of Aquatic Sciences, 2017, 12(4), 333-342.

CASIMIRO, A.C.R., GARCIA, D.A.Z., VIDOTTOMAGNONI, A.P., BRITTON, J.R., AGOSTINHO, A.A., DE ALMEIDA, F.S. and ORSI, M.L. Escapes of non-native fish from flooded aquaculture facilities: the case of Paranapanema River, southern Brazil. Zoologia, 2018, 35, e14638. http://dx.doi. org/10.3897/zoologia.35.e14638.

CASSEMIRO, F.A.S., BAILLY, D., DA GRAÇA, W.J. and AGOSTINHO, A.A. The invasive potential of tilapias (Osteichthyes, Cichlidae) in the Americas. Hydrobiologia, 2018, 817(1), 133-154. http://dx.doi. org/10.1007/s10750-017-3471-1.

CASTAGNOLLI, N. Aquicultura para o ano 2000. Brasília: CNPq, 1996.

CUCHEROUSSET, J. and OLDEN, J.D. Ecological impacts of nonnative freshwater fishes. Fisheries (Bethesda, Md.), 2011, 36(5), 215-230. http://dx.doi. org/10.1080/03632415.2011.574578.

DOUËLLOU, L. and ERLWANGER, K.H. Crustacean parasites of fishes in Lake Kariba, Zimbabwe, preliminary results. Hydrobiologia, 1994, 287(3), 233-242. http://dx.doi.org/10.1007/BF00006372.

DOUËLlOU, L. Monogeneans of the genus Cichlidogyrus Paperna, 1960 (Dactylogyridae: Ancyrocephalinae) from cichlid fishes of Lake Kariba (Zimbabwe) with descriptions of five new species. Systematic Parasitology, 1993, 25(3), 159-186. http:// dx.doi.org/10.1007/BF00007007.

EIRAS, J.C. Elementos de Ictioparasitologia. Porto: Fundação Eng. António de Almeida, 1994.

EIRAS, J.C., TAKEMOTO, R.M. and PAVANELLI, G.C. Métodos de estudo e técnicas laboratoriais em parasitologia de peixes. Maringá: EDUEM, 2000.

ERGENS, R. and YUKHIMENKO, S.S. Contribution to the knowledge of Gyrodactylus gurleyi Price, 1937 (Monogenea: Gyrodactylidae). Folia parasitologica, 1987, 34(3), 205-209. PMid:3666611. 
ESCHMEYER, W.N., FRICKE, R. and VAN DER LAAN, R. Catalog of fishes: genera, species, references. 2017 [viewed 30 November 2017]. Available from: http://www.calacademy.org/scientists/projects/ catalog-of-fishes/

FIGUEREDO, C.C. and GIANI, A. Ecological interactions between Nile tilapia (Oreochromis niloticus, L.) and the phytoplanktonic community of the Furnas Reservoir (Brazil). Freshwater Biology, 2005, 50(8), 1391-1403. http://dx.doi.org/10.1111/ j.1365-2427.2005.01407.x.

FRANÇA, E.J., ALMEIDA, C.A.C., ALMEIDANETO, M.S., SANTOS, R.E., MAGALHÁES, A.L.B., EL-DEIR, A.C.A. and SEVERI, W. Novelty on the market, novelty in the environment: The invasion of non-native fish jaguar guapote (Perciformes) in northeastern Brazil. Neotropical Biology and Conservation, 2017, 12(1), 12-18. http:// dx.doi.org/10.4013/nbc.2017.121.02.

FROESE, R. and PAULY, D. FishBase. 2017 [viewed 30 November 2017]. Available from: http://www. fishbase.org

GAlli, P., CROSA, G., BERTOGLIO, S., MARINIELLO, L., ORTIS, M. and AMELIO, S.D. Populations of Lamproglena pulchella von Nordmann, 1832 (Copepoda: Eudactylinidae) in cyprinid fish in rivers with different pollution levels. Journal of Applied Ichthyology, 2001, 17(2), 93-96. http:// dx.doi.org/10.1046/j.1439-0426.2001.00282.x.

GHIRALDELLI, L., MARTINS, M.L., JERÔNIMO, G.T., YAMASHITA, M.M. and ADAMANTE, W.B. Ectoparasites communities from Oreochromis niloticus cultivated in the state of Santa Catrina, Brazil. Su Ürünleri Dergisi, 2006a, 1(2), 181-190.

GHIRALDELLI, L., MARTINS, M.L., YAMASHITA, M.M. and JERÔNIMO, G.T. Ectoparasites influence on the hematological parameters of Nile tilapia and carp cultured in the State of Santa Catarina, Brazil. Su Ürünleri Dergisi, 2006b, 1(3), 270-276.

GOEDKNEGT, M.A., FEIS, M.E., WEGNER, K.M., LUTTIKHUIZEN, P.C., BUSCHBAUM, C., CAMPHUYSEN, K.C., VAN DER MEER, J. and THIELTGES, D.W. Parasites and marine invasions: ecological and evolutionary perspectives. Journal of Sea Research, 2016, 113(1), 11-27. http://dx.doi. org/10.1016/j.seares.2015.12.003.

GOZLAN, R.E., BRITTON, J.R., COWX, I. and COPP, G.J. Current knowledge on non-native freshwater fish introductions. Journal of Fish Biology, 2010, 76(4), 751-786. http://dx.doi.org/10.1111/ j.1095-8649.2010.02566.x.

HASSAN, E.S., MAHMOUD, M.M., METWALLY, A.M. and MOKHTAR, D.M. Lamproglena monodi (Copepoda: lernaeidae), infesting gills of Oreochromis niloticus and Tilapia zillii. Global Journal of Fisheries and Aquaculture Researches, 2013, 6(6), 1-16.
IBRAHEEM, M.H. and IZAWA, K. On the morphology of Lamproglena monodi Capart, a parasitic copepod on the gills of Tilapia in Egypt. Zoology in the Middle East, 2000, 21(1), 103-108. http://dx.doi.org/10.10 80/09397140.2000.10637837.

JERÔNIMO, G.T., SPECK, G.M., CECHINEL, M.M., GONÇALVES, E.L.T. and MARTINS, M.L. Seasonal variation on the ectoparasitic communities of Nile tilapia cultured in three regions in southern Brazil. Brazilian Journal of Biology $=$ Revista Brasileira de Biologia, 2011, 71(2), 365-373. http:// dx.doi.org/10.1590/S1519-69842011000300005. PMid:21755153.

JIMÉNEZ-GARCÍA, M.I., VIDAL-MARTÍNEZ, V.M. and LÓPEZ-JIMÉNEZ, S. Monogeneans in introduced and native cichlids in México: evidence for transfer. The Journal of Parasitology, 2001, 87(4), 907-909. http://dx.doi.org/10.2307/3285151. PMid:11534657.

KRITSKY, D.C. and THATCHER, V.E. Monogenetic trematodes (Monopisthocotylea: Dactylogyridae) from freshwater fishes of Colombia, South America. Journal of Helminthology, 1974, 48(1), 59-66. http://dx.doi.org/10.1017/S0022149X00022604. PMid:4825435.

KRITSKY, D.C., VIDAL-MARTINEZ, V.M. and RODRIGUEZ-CANUL, R. Neotropical Monogenoidea. 19. Dactylogyridae of Cichlids (Perciformes) from the Yucatan Peninsula, with Descriptions of Three New Species of Sciadicleithrum Kritsky, Thatcher, and Boeger, 1989. Journal of the Helminthological Society of Washington, 1994, 61(1), 26-33.

KUMARI, P., KHERA, S. and GUPTA, N.K. On six new species of the genus Lamproglena Nordmann (Copepoda: Eudactylinidae), ectoparasitic on freshwater fishes of India. Research Bulletin of the Panjab University Science, 1989, 40(1), 9-23.

LANGEANI, F., CASTRO, R.M.C., OYAKAWA, O.T., SHIBATTA, O.A., PAVANELLI, C.S. and CASATTI, L. Diversidade da ictiofauna do Alto Rio Paraná: composição atual e perspectivas futuras. Biota Neotropica, 2007, 7(3), 181-197. http://dx.doi. org/10.1590/S1676-06032007000300020.

LEPRIEUR, F., BEAUCHARD, O., BLANCHET, S., OBERDORFF, T. and BROSSE, S. Fish invasions in the world's river systems: when natural processes are blurred by human activities. PLoS Biology, 2008, 6(2), e28. http://dx.doi.org/10.1371/journal. pbio.0060322. PMid:18254661.

LIZAMA, M.A.P., TAKEMOTO, R.M., RANZANIPAIVA, M.J.T., AYROZA, L.M.S. and PAVANELLI, G.C. Relação parasito-hospedeiro em peixes de pisciculturas da região de Assis, Estado de São Paulo, Brasil. 1. Oreochromis niloticus (Linnaeus, 1758). Acta Scientiarum. Biological Sciences, 2007, 29(2), 
223-231. http://dx.doi.org/10.4025/actascibiolsci. v29i2.594.

MAITHYA, J., NJIRU, M., OKEYO-OWUOR, J.B. and GICHUKI, J. Some aspects of the biology and life-history strategies of Oreochromis variabilis (Boulenger 1906) in the Lake Victoria Basin. Lakes \& Reservoirs, 2012, 17(1), 65-72. http://dx.doi. org/10.1111/j.1440-1770.2012.00496.x.

MARTIN, C.W., VALENTINE, M.M. and VALENTINE, J.F. Competitive interactions between invasive Nile tilapia and native fish: the potential for altered trophic exchange and modification of food webs. PLoS One, 2010, 5(12), e14395. http://dx.doi.org/10.1371/journal.pone.0014395. PMid:21200433.

MARTINS, M.L., AZEVEDO, T.M., GHIRALDELLI, L. and BERNARDI, N. Can the parasitic fauna on Nile tilapias be affected by different production systems? Anais da Academia Brasileira de Ciências, 2010, 82(2), 493-500. http://dx.doi.org/10.1590/ S0001-37652010000200024. PMid:20563429.

MARTINS, M.L., SÁ, A.R.S., JERÔNIMO, G.T., TANCREDO, K.R., GONÇALVES, E.L.T., BAMPI, D., SPECK, G.M. and SANDIN, A.M. Microhabitat preference and seasonality of gill monogeneans in Nile Tilapia reared in Southern Brazil. Neotropical Helminthology, 2014, 8(1), 47-58.

MARZOUK, M.S.M., MAHDY, O.A., EL-KHATIB, N.R. and YOUSEF, N.S.I. A contribution in ectoparasitic infection and its control in cultured Oreochromis niloticus in Egypt. American Journal of Research Communication, 2013, 1(12), 326-338.

MCCRARY, J.K., MURPHY, B.R., STAUFFER JUNIOR, J.R. and HENDRIX, S.S. Tilapia (Teleostei: Cichlidae) status in Nicaraguan natural waters. Environmental Biology of Fishes, 2007, 78(2), 107-114. http://dx.doi.org/10.1007/s10641-0069080-x.

NOGA, E.J. and FLOWERS, J.R. Invasion of Tilapia mossambica (Cichlidae) viscera by the monogenean Enterogyrus cichlidarum. The Journal of Parasitology, 1995, 81(5), 815-817. http://dx.doi. org/10.2307/3283988. PMid:7472888.

OGUTU-OHWAYO, R. The decline of the native fishes of lakes Victoria and Kyoga (East Africa) and the impact of introduced species, especially the Nile perch, Lates niloticus, and Nile tilapia, Oreochromis niloticus. Environmental Biology of Fishes, 1990, 27(2), 81-96. http://dx.doi.org/10.1007/BF00001938.

ORSI, M.L. and BRITTON, J.R. Long-term changes in the fish assemblage of a neotropical hydroelectric reservoir. Journal of Fish Biology, 2014, 84(6), 1964-1970. http://dx.doi.org/10.1111/jfb.12392. PMid:24787281.

PANTOJA, W.M.F., NEVES, L.R., DIAS, M.K.R., MARINHO, R.G.B., MONTAGNER, D. and
TAVARES-DIAS, M. Protozoan and metazoan parasites of Nile tilapia Oreochromis niloticus cultured in Brazil. Revista Mvz Cordoba, 2012, 17(1), 28122819. http://dx.doi.org/10.21897/rmvz.248.

PAPERNA, I. and THURSTON, J.P. Monogenetic Trematodes collected from cichlid fish in Uganda; including the description of five new species of Cichlidogyrus. Revue de Zoologie et de Botanique Africaines, 1969, 79(1-2), 15-33.

PAPERNA, I. Parasitic helminths of inland-water fishes in Israel. Israel Journal of Zoology, 1964, 13(1), 1-26.

PARISELLE, A. and EUZET, L. Scutogyrus gen. n. (Monogenea: Ancyrocephalidae) for Cichlidogyrus longicornis minus Dossou, 1982, C. l. longicornis, and C. l. gravivaginus Paperna and Thurston, 1969, with description of three new species parasitic on african cichlids. Journal of the Helminthological Society of Washington, 1995, 62(2), 157-173.

PARISELLE, A. and EUZET, L. Systematic revision of dactylogyridean parasites (Monogenea) from cichlid fishes in Africa, the Levant and Madagascar. Zoosystema, 2009, 31(4), 849-898. http://dx.doi. org/10.5252/z2009n4a6.

PARISELLE, A., BILONG, C.F.B. and EUZET, L. Four new species of Cichlidogyrus Paperna, 1960 (Monogenea, Ancyrocephalidae) all gill parasites from African mouthbreeder tilapias of the genera Sarotherodon and Oreochromis (Pisces, Cichlidae), with a re-description of $C$. thurstonae Ergens, 1981. Systematic Parasitology, 2003, 56(3), 201-210. http:// dx.doi.org/10.1023/B:SYPA.0000003807.27452.bd. PMid:14707506.

PIASECKI, W. Comparative morphology of the three species of Lamproglena (Copepoda, Cyclopoida, Lernaeidae) described by von Nordmann, based on re-examination of the types. Zoosystematics and Evolution, 2008, 69(2), 307-315.

PRENTER, J., MACNEIL, C., DICK, J.T.A. and DUNN, A.M. Roles of parasites in animal invasions. Trends in Ecology \& Evolution, 2004, 19(7), 385390. http://dx.doi.org/10.1016/j.tree.2004.05.002. PMid:16701290.

PRIETO, A., FAJER, E. and VINJOY, M. Cichlidogyrus sclerosus (Monogenea: Ancyrocephalinidae) in Tilapia hornorum x Tilapia mossambica (perca dorada) en cultivo intensivo. Revista de Salud Animal, 1985, 7 , 291-295.

SANCHES, F.H.C., MIYAI, C.A., COSTA, T.M., CHRISTOFOLETTI, R.A., VOLPATO, G.L. and BARRETO, R.E. Aggressiveness overcomes body-size effects in fights staged between invasive and native fish species with overlapping niches. PLoS One, 2012, 7(1), e29746. http://dx.doi.org/10.1371/ journal.pone.0029746. PMid:22272244.

SCHORK, G., HERMES-SILVA, S. and ZANIBONIFILHO, E. Analysis of fishing activity in the Itá 
reservoir, Upper Uruguay River, in the period 2004-2009. Brazilian Journal of Biology = Revista Brasileira de Biologia, 2013, 73(3), 559-571. http:// dx.doi.org/10.1590/S1519-69842013000300014. PMid:24212697.

Š I M K O VÁ, A. , ¿̌́ E H U L K O VÁ, E., RASOLOARINIAINA, J.R., JORISSEN, M.W.P., SCHOLZ, T., FALTÝNKOVÁ, A., MAŠOVÁ, Š. and VANHOVE, M.P.M. Transmission of parasites from introduced tilapias: a new threat to endemic Malagasy ichthyofaunal. Biological Invasions, 2019, 21(3), 803-819. http://dx.doi.org/10.1007/s10530018-1859-0.

SINARÉ, Y., BOUNGOU, M., OUÉDA, A., GNÉMÉ, A. and KABRÉ, G.B. Diversity and seasonal distribution of parasites of Oreochromis niloticus in semi-arid reservoirs (West Africa, Burkina Faso). African Journal of Agricultural Research, 2016, 11(13), 1164-1170. http://dx.doi.org/10.5897/ AJAR2015.10408.

TAVARES-DIAS, M. Piscicultura continental no estado do Amapá: diagnóstico e perspectivas. Amapá: Embrapa, 2011. Boletim de Pesquisa e Desenvolvimento.

TAVARES-DIAS, M., DIAS-JÚNIOR, M.B., FLORENTINO, A.C., SILVA, L.M. and CUNHA, A.C. Distribution pattern of crustacean ectoparasites of freshwater fish from Brazil. Revista Brasileira de Parasitologia Veterinária, 2015, 24(2), 136-147.
http://dx.doi.org/10.1590/S1984-29612015036. PMid:26154954.

TREWAVAS, E. Tilapiine fishes of the genera Sarotherodon, Oreochromis and Danakilia. London: British Museum, 1983. Natural History, no. 878. https:// doi.org/10.5962/bhl.title.123198.

YAMAMOTO, K., TAKAGI, S. and MATSUOKA, $S$. Mass mortality of the Japanese anchovy (Engraulis japonica) caused by a gill monogenean Pseudanthocotyloides sp. (Mazocraeidae) in the Sea of Iyo ("Iyo-nada"), Ehime Prefecture. Fish Pathology, 1984, 19(2), 119-123. http://dx.doi.org/10.3147/ jsfp.19.119.

YAMBOT, A.V. and LOPEZ, E.A. Gill parasite, Lamproglena monodi Capart, infecting the Nile tilapia, Oreochromis niloticus L., cultured in the Phillipines. In: Proceedings of the 3rd Symposium on Diseases in Asian Aquaculture. Manila: Asian Fisheries Society, 1997. pp. 175-177.

ZAGO, A.C., FRANCESCHINI, L., GARCIA, F., SCHALCH, S.H.C., GOZI, K.S. and SILVA, R.J. Ectoparasites of Nile tilapia (Oreochromis niloticus) in cage farming in a hydroelectric reservoir in Brazil. Revista Brasileira de Parasitologia Veterinária, 2014, 23(2), 171-178. http://dx.doi.org/10.1590/S198429612014041. PMid:25054495.

Received: 09 September 2018 Accepted: 18 October 2019 